\title{
THE ROLE OF TEACHER PERFORMANCE ASSESSMENT (PKG) ON TEACHERS PERFORMANCE AT SMKN 2 JEMBER
}

\author{
Dian Narulita Tristina ${ }^{1}$ \\ Suwignyo Widagdo² \\ Murtadlo 3 \\ Higher Education of Economic Mandala \\ Email :stie-mj@stie-mandala.ac.id
}

\begin{abstract}
The purpose of this researchwasto identify and analyze the aspects of Teacher Performance Assessment (PKG, in Indonesian language is Penilaian Kinerja Guru) on teacher's performance. The hypothesis of this researchreads the aspects of teacher performance assessment (PKG) partially significant effect on teacher's performance. The population in this researcharecivil servant teachers of SMKN 2Jember. This research used a Simple Random Samplingtechniquesince the sampling was done randomly without regarding to strata contained in the population and the whole population are teachers of SMKN 2 Jember. The samples in this researchare71civil servant teachers in SMKN 2 Jember. Data collection methods used in this research are observation, interview, questionnaires and documentation. The implications of the findings of this study may contribute to the development of science and for practitioners. The result of this research was to improve the teacher's performance, then the aspects of PKG should be improved. This was in accordance with the concept of human resources. Some suggestions can be given was the results of this study indicate that aspects of the Teacher Performance Assessment (PKG) gave significant effect on performance partially.
\end{abstract}

Keywords: Teacher Performance Assessment (PKG), performance

\section{INTRODUCTION}

The teacher is an educator who is expected to work optimally due to improve the competence in terms of knowledge, skills and attitudes of learners. Teachers can work optimally when four competencies, namely (1) the pedagogic; (2) personality; (3) social and (4) professional which suitable with National Education Minister Regulation No. 16 of 2007 on
Academic Qualification Standards and Competencies of Teachers (Kemendikbud, 2012: 5-6).

Fourth competencies which must have by teacher is write on the Teacher Performance Assessment (PKG). According to the Regulation of the Minister of State for Administrative Reform and Bureaucratic Reform No. 16 of 2009, the Teacher Performance Assessment is an assessment of the 
activities of each item of her main tasks in order to develop a career, rank and position. The implementation of the main duty of teachers can not be separated from the teacher's ability in the mastery of knowledge, application of knowledge and skills, as competencies required as writed on National Education Minister Regulation No. 16 of 2007 on Academic Qualification Standards and Teacher Competency. Mastery of competencies and application of knowledge and skills of teachers, will determine the achievement of quality learning or coaching learners, and the implementation of additional tasks that are relevant to the school / madrasah, especially for teachers with the additional task. Teacher Performance Assesment System (PKG) is a system ability designed to identify teachers to perform their duties through the measurement of competence mastery in performance (Ministry of Education and Culture, 2012).

The adventages of the Teacher

Performance Assessment is to determine policies related to improving the quality and performance of teachers as spearhead the implementation of the educational process in creating an intelligent human being, comprehensive, and highly competitive. PKG is a reference for school / madrasah to establish career development and promotion of teachers. For teachers, the PKG is a guideline to determine the elements of performance are assessed and the means to determine individual strengths and weaknesses in order to improve the quality of performance (Kemendikbud, 2012: 3).
Mastery of competencies and application of knowledge and skills of teachers, will determine the achievement of quality learning or mentoring learners. Past research conducted by Lathifiah (2016) discusses theinfluence of PKG and organizational culture on the performance of teachers in the district SMPI Ciawi Bogor, West Java. The results showed that Teacher Performance Assessment (PKG) gave partially significant effect on the performance of teachers in the district teachers SMPI Ciawi Bogor, West Java. The phenomena is a problem in SMKN 2 Jember is not all teachers have performed as expected, both from the quality, quantity, time efficiency work in realizing the vision and mission. When was done classroom supervision PKG, then the teacher will make preparation possible with a good variety of teaching methods in order to made the classbetter than everyday teaching and learning conditions. Rights and obligations are always together .As teacher has competeciest and professional teachers will get professional allowance. With the benefits of the teaching profession is expected they increase compesation teachers in order to transfer knowledge to the learners. Teachers have been given the compensation rights with duties of a teacher. Based on the phenomenon that has been described above, this study discusses the role of aspects of the Teacher Performance Assessment (PKG) on the performance of teachers at SMKN 2 Jember. The problems concerning the PKG influence the performance of teachers at SMKN 2 Jember discussed in this research is formulated as follows: is there was a significant effect of Teacher Performance Assessment (PKG) on the teacher's performance? Based on the formulation of the problem above, we 
can identify the purpose of the reaserch was to determine and analyze the aspects of the Teacher Performance Assessment (PKG on teacher's performance. Based on the identification of problems that have been found, this research was limited to respondents aspect Teacher Performance Assessment (PKG), a civil servant teachers The SMKN 2 Jember environment.

\section{RESEARCH METHOD}

This research was conducted at SMKN 2 Jember which located on Jl. Tawangmangu No. 59 Jember in November 2016.

This study used a sampling Simple

Randomsamplingtechnique.Reasearch used samplingsince the sampling is done randomly without regard to strata contained in the population and the whole population was teachers at SMKN 2 Jember.

Technique is used with simple random sampling the formula of Slovin (Juliansyah Noor, 2011: 158), since SMKN 2 Jember divided into departments and teacher NA, then from each department and teacher NA will take some samples teachers according to the number of teachers in schools with a 5\% error level, namely:

$$
\mathrm{n}=\underline{\mathrm{n}}
$$

From the results of these calculations is 70.78 then rounded to 71 respondents. Each researcher has a reason in determining the number of respondents. Whether using a random sampling or popolation or the other. This research using random sampling, which each respondent has a probability equal to the other respondents. List of respondents in the data first and then do the draw. The name that appears become respondents in the reaserch. This resaerch uses 71 respondents respondents due to several things: 1) require the minimum number of respondents using the Slovin formula, 2) save time and cost when compared to the overall sample, 3) it can give depth information. In addition, the number of 71 respondent was considered good sample. Namely the objective reepresentatif and on time / puntual. datamay provide a more in-depth and thorough.

\section{RESEARCH RESULTS ANALYSIS}

To determine the effect of independent variables (PKG) on the dependent variable (performance) partially used $t$ test, where this test comparing the t-test with a t-table results of tests on each variable teacher performance assessment, workplace culture and leadership on performance.

Table Summary of Results of t test

\begin{tabular}{|c|c|c|c|}
\hline Variable & t-test & $\begin{array}{c}\mathrm{t}- \\
\text { table } \\
.\end{array}$ & Sig \\
\hline $\begin{array}{c}\text { Teacher } \\
\text { evaluations } \\
\text { are (X1) }\end{array}$ & 2.169 & $\begin{array}{c}1.99 \\
6\end{array}$ & $\begin{array}{c}0.03 \\
\text { Working }\end{array}$ \\
$\begin{array}{c}\text { culture (X2) } \\
\text { Leadership } \\
\text { (X3) }\end{array}$ & 2.383 & & 0.02 \\
0 \\
\hline
\end{tabular}

Based on the table above the known value of t-test variable teacher performance assessmentwas equal to 2,169 with a probability value of 0,034 , while the value of the t-table amounted to 1.996 (Appendix 11), so that $t$ count> t-table (2.169> 1.996). That was indicated that the variable aspects of teacher performance assesment partially have a significant effect on teach 
performance. PKG has an influence on the performance due to the high ability of teachers to communicate with students, as well as their efforts to increase the ability of mastery learning theory and principles of learning. So it can support the hypothesis, Aspect Teacher Performance Assessment (PKG) gave partially significant effect on performance.

\section{INTERPRETATION}

Based on the result analysis above showed that the effect aspects of Teacher Performance Assessment (PKG) gived effect on teacher performance SMKN 2 Jember. Were the result. Were the result that were known value of t-test variable aspects of teacher performance appraisal is equal to 2,169 with a probability value of 0.034 , while the value of the t-table amounted to 1.996 (Appendix 11), so that $\mathrm{t}$ count $>\mathrm{t}$-table $(2.169>1.996)$. This indicates that the variable aspects of teacher performance appraisal partially have a significant effect on performance.

The results were consistent with the hypothesis of the study, which reads "Aspects of Teacher Performance Assessment (PKG) partially affect the performance". This proves that aspect Teacher Performance Assesment (PKG) can support teachers in doing the work, because the performance is also influenced by aspects of Teacher Performance Assessment (PKG).

Teacher

Performance

Assessment (PKG) is also an instrument that is used in the performance evaluation as part of the implementation of performance management, as stated by Syafarudin that performance evaluation is one part of performance management, which is the process in which the performance of the individual and evaluated is used to answer the question, "How good is the performance of a teacher in a given period?" (2005: 178).

Assessment aspect Teacher Performance (PKG) owned by teachers of SMK 2 Jember very good. Most teachers understand the four component aspects Penialaian Teacher Performance (PKG), namely pedagogy, personality, social and professional. The most dominant indicator is to establish good communication with learners. This shows that most of the teachers at SMKN 2 Jember able to convey messages either unidirectional or bidirectional well her students.

The evaluation of the teacher's performance is packaged in the form of teacher performance assesment. On the other hand, with the Teacher Performance Assessment is one of several awards for teachers, because the results can be used for the proposed promotion of civil service teachers. Teachers who have an understanding and implementing aspects of the Teacher Performance Assessment (PKG) which either will do the job with full responsibility, teachers will also increase the quality of its performance. Conversely, if a teacher has a low understanding and applying, be lazy and their own way of working. Teachers are lazy at work will be able to affect its performance which led to the achievement of low performance.

The results of this research was ini line with the results conducted by Lathifah (2016) which showed the significant effect aspects of the Teacher Performance Assessment (PKG) on teacher performance partialy. 


\section{CONCLUSION}

Based on the results analysis and a discussion about the effect of Teacher Performance Improvement System (PKG) on the teacher's performance at SMK Negeri 2 Jember, it was concluded that to improve teacher performance can be improved through PKG. The conclution of this hypothesis of this research the following: 1) improving teacher performance can be supported by the teacher's ability to communicate with students. 2) Improving the teachers performance can be supported with the high responsibility of the teacher to the workload. 3) Improving the performance of teachers can be supported with the ability to complete the tasks assigned on time. 4) Improving teachers performance will become more effective and efficient if teachers are able to apply with the same ability to establish communication with learners, responsibilities of teachers to the workloads, the ability to complete assigned tasks on time.

\section{IMPLICATIONS}

The implications of this findings this research could give contribution on the development of science and for practitioners as follows: This research supports the theory and research which states that: (1) Aspects of teacher performance assesment (PKG) is partially significant effect on the teacher's performance at SMK Negeri 2 Jember

The end result of this research is to improve the performance, then the PKG aspects, should be improved.
This is consistent with the concept of human resources.

\section{REFERENCES}

Arif dan Farid. 2011. Pengaruh Kepemimpinan, Stres Kerja, Disiplin Kerja dan Kompensasi dengan Kinerja Pegawai. Jurnal Ekonomi Manajemen Sumber Daya. Vol. 12, No. 1, Juni 2011.

Baihaqi ,Muhammad Iqbal .2015. Pengaruh Gaya Kepemimpinan Kepala Sekolah Dan Motivasi Kerja Terhadap Kinerja Guru Di Ma A'arif Selorejo Blitar. Jurnal Konstruktivisme, Vol. 7, No. 2, Juli 2015: FKIP Universitas IslamBalitar,Blitar

Dharma, Agus. 2003. Manajemen Supervisi:Petunjuk Praktis Bagi Para Supervisor.

Edisi Revisi. Cetakan kelima. Jakarta: Raja Grafindo Persada.

Dimyati, Mohamad.2009. Analisis SEM dakamUjiPengaruhBeberapaVariab elTerhadapLoyalitas, KajianBerbasisRisetpadaDebiturKr edit Usaha Kecil.Jakarta: MitraWacana Media.

Depdikbud. (2012). Buku Pedoman Pelaksanaan Penilaian Kinerja Guru. Jakarta.

Ferdinand, Augusty. 2006. Metode Penelitian Manajemen: Pedoman Penelitian untuk Skripsi, Tesis dan Disertasi Ilmu Manajemen, Semarang: Badan Penerbit Universitas Diponegoro.

Gering Supriyadi, 2003., Budaya Kerja Organisasi Pemerintah, Bahan Ajar Diklat Prajabatan Golongan I dan II, Lembaga Administrasi Negara.

Gering, Supriyadi dan Triguno. 2001. Budaya Kerja Organisasi Pemenrintah.. Jakarta. Lembaga Administrasi Negara. 
Hasibuan, Malayu SP. 2008. ManajemenSumberDayaManusia . Jakarta: PT. BumiAksara

Hasibuan, Malayu SP. 2005. ManajemenPrestasiKerja. Jakarta: Rajawali

Istianto, Bambang. 2011. Manajemenpemerintahandalam perspektifpelayananpublik.Jakar ta: Raja GrafindoPersada

Kementrian Pendidikan Dan Kebudayaan. (2012). Pedoman Pelaksanaan Penilaian Kinerja Guru: Pembinaan dan Pengembangan Profesi Guru Buku 2. Diunduh dari www.slideshare.net/purdiyanto /penilaian-kinerja-guru-pkg diakses tanggal oktober 2016 pukul 11:08.

Lathifah, Zahra Khusnul 2016. Pengaruh Penilaian Kinerja Guru (PKG) dan Budaya Organisasi Terhadap Kinerja Guru di Sekolah Menengah Pertama Islam (SMPI) di Kecamatan Ciawi Bogor Jawa Barat.Tesis Program Pascasarjana. IAIN Surakarta.

Noor, Juliansyah. (2011). Metodologi Penelitian: Skripsi, Tesis, Disertasi, dan Karya IImiah. Jakarta: Kencana Prenada Media Group.

Ndraha, Talidziduhu. (2005). Teori Budaya Organisasi. Jakarta: Rineka Cipta

Ndraha, Talidziduhu. (1997). Budaya Organisasi. Jakarta : PT Rineka Cipta

Pramono, Harry.2012. Pengaruh Sistem Pembinaan, Sarana Prasarana Dan Pendidikan Latihan Terhadap Kompetensi Kinerja Guru Pendidikan Jasmani Sekolah Dasar Di Kota Semarang
- Jurnal Penelitian Pendidikan Vol. 29 Nomor 1 tahun 2012. Fakultas Ilmu Keolahragaan, Universitas Negeri Semarang

Rivai Veithzal. 2008. Kepemimpinan dan Perikaku Organisasi. Edisi Kedua. Jakarta : PT. Raja Grafindo Persada.

Riyadi,

Slamet.

2011.PengaruhKompensasiFinansi

al, Gaya Kepemimpinan, danMotivasiKerjaTerhadapKinerja KaryawanpadaPerusahaan

Manufaktur di JawaTimur.Surabaya :Universitas 17 Agustus 1945

Sugiono.(2007). Metode Penelitian Kuantitatif, Kualitatif, fan R\&D. Bandung: Alfabeta.

Sedarmayanti,2008. Manajemen Sumber Daya Manusia, Reformasi Birokrasi dan Manajemen PNS. Bandung: PT. RefikaAditama.

Siagian,P.Sondang.2007.Manajemen Sumber Daya Manusia. Cetakan ke 15.Jakarta: PT.BumiAksara

Sugiyono. 2012. MetodePenelitianBisnis.Bandung:Al fabeta 2010.StatistikuntukPenelitian, Bandung: Alfabeta

Suryani, Susi. 2013.PengaruhBudayakerjaTerhad apKinerja Guru dalam Proses BelajarMengajarSekolahMenengah Atas Dan Kejuruan di KecamatanPrambanan.Skripsi Program StudiManajemenPendidikan. UNY

Soetopo, MeitaPragiwani. 2016. Pengaruhkepemimpinan, pendidikandanpelatihanMotivasike rja, danbudayaorganisasiTerhadapkom petensidankinerja guru. Jurnal STEI Ekonomi Volume 25 - Nomor 1, Juni 
2016.SekolahTinggillmuEkonom i Indonesia

Sadar. 2015. HubunganPersepsi Gaya KepemimpinanKepalaSekolah Dan EfikasiDiriDenganKinerjaGuru.T esis program magister psikologisekolahpascasarjana :Universitasmuhammadiyah Surakarta.

Syafaruddin, (2005). Manajemen Lembaga Pendidikan Islam. Jakarta: PT. Ciputat.Press
Saifuddin Azwar. (2012). Penyusunan Skala Psikologi. Yogyakarta: Pustaka Pelajar.

Wursanto, Ig., (2002). Dasar-dasar Ilmu Organisasi. Yogyakarta: Andi Publisher

Yukl, Gary. 1998. Kepemimpinan dalam Organisasi Leadership in Organizations 3e. Jakarta:Prenhalindo

\section{BIOGRAPHY}

Dian Narulita Tristina, S.Pd,MM was born 30 years ago, in Jember on January 16, 1987. She is the first child from the couple of Drs. Sutrisno, M.Si and Mrs. Dra.Suhartini. Wife of Agus Dedi Mustafa, S.Pd.T,MM study at SDN Patrang last in 1998. It is said of most recent change schools because she moved to other school 4 times due to follow the duty of parents as the school perfect of Education. Her hinger education, junior high shool and high school she take at SMPN 1 Jember graduated in 2001 and MAN 1 Jember graduated in 2004. Mother for three children continue her studies at the University of Jember especally at Faculty of Teacher Trains and education concern study Indonesia language. Then, this civil servant teacher continue her study of post graduate at STIE MANDALA Jember. 